\title{
Myelodysplasia-associated mutations in serine/arginine-rich splicing factor SRSF2 lead to alternative splicing of CDC25C
}

\author{
Lindsey Skrdlant ${ }^{1}$, Jeremy M. Stark ${ }^{2}$ and Ren-Jang Lin ${ }^{1^{*}}$ (1)
}

\begin{abstract}
Background: Serine-arginine rich splicing factor 2 (SRSF2) is a protein known for its role in RNA splicing and genome stability. It has been recently discovered that SRSF2, along with other splicing regulators, is frequently mutated in patients with myelodysplastic syndrome (MDS). The most common MDS mutations in SRSF2 occur at proline 95; the mutant proteins are shown to have different RNA binding preferences, which may contribute to splicing changes detected in mutant cells. However, the influence of these SRSF2 MDS-associated mutations on specific splicing events remains poorly understood.

Results: A tetracycline-inducible TF-1 erythroleukemia cell line was transduced with retroviruses to create cell lines expressing HA-tagged wildtype SRSF2, SRSF2 with proline 95 point mutations found in MDS, or SRSF2 with a deletion of one of the four major domains of the protein. Effects of these mutants on apoptosis and specific alternative splicing events were evaluated. Cells were also treated with DNA damaging drugs for comparison. MDS-related P95 point mutants of SRSF2 were expressed and phosphorylated at similar levels as wildtype SRSF2. However, cells expressing mutant SRSF2 exhibited higher levels of apoptosis than cells expressing wildtype SRSF2. Regarding alternative splicing events, in nearly all examined cases, SRSF2 P95 mutants acted in a similar fashion as the wildtype SRSF2. However, cells expressing SRSF2 P95 mutants had a percent increase in the C5 spliced isoform of cell division cycle 25C (CDC25C). The same alternative splicing of CDC25C was detected by treating cells with DNA damaging drugs, such as cisplatin, camptothecin, and trichostatin A at appropriate dosage. However, unlike DNA damaging drugs, SRSF2 P95 mutants did not activate the Ataxia telangiectasia mutated (ATM) pathway.
\end{abstract}

Conclusion: SRSF2 P95 mutants lead to alternative splicing of CDC25C in a manner that is not dependent on the DNA damage response.

Keywords: SRSF2, Myelodysplastic syndromes, RNA splicing, CDC25C, DNA damage response

\section{Background}

Serine-arginine rich splicing factor 2 (SRSF2), previously named SC35, is a member of the SR protein family of splicing regulators. The primary role of SR proteins is to regulate splice site selection for both constitutive and alternative splicing. In addition to their role in splicing, SR proteins are also involved in the maintenance

\footnotetext{
*Correspondence: RLin@coh.org

${ }^{1}$ Department of Molecular and Cellular Biology, Irell \& Manella Graduate School of Biological Sciences, Beckman Research Institute of the City of Hope, Duarte, CA 91010, USA

Full list of author information is available at the end of the article
}

of genome stability through the prevention of R-loop structure formation during transcription [1-4]. Structurally, SRSF2 can be divided into specific protein domains (Fig. 1a). The RNA recognition motif (RRM) is involved in binding to exonic or intronic splicing enhancers in the nascent pre-mRNA transcript. The eponymous serine-arginine rich domain (RS) is primarily involved in protein-protein interactions with other spliceosomal components and with the 7SK complex involved in transcriptional elongation $[3,5,6]$. In addition, serine phosphorylation at the RS domain significantly affects the subnuclear localization and functions of SRSF2 [7-11]. 


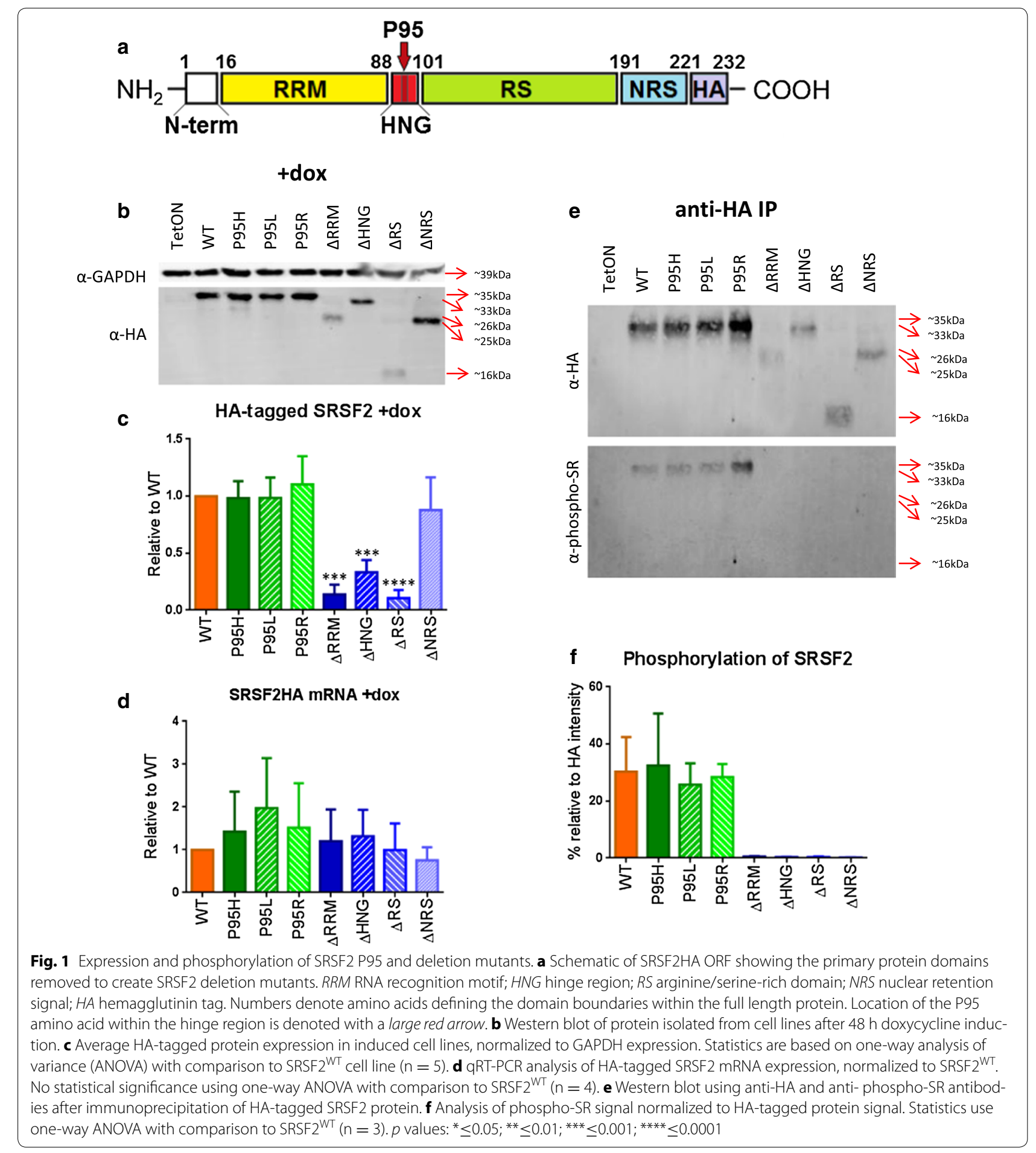

The short amino acid sequence between the RRM and RS domains is the hinge region (HNG). The exact function of this region is largely unknown, though studies with SRSF1 (ASF/SF2) suggest that it may have an important role in kinase docking [12]. The last major domain of SRSF2 is the nuclear retention signal (NRS) at the C-terminal end of the protein, which is unique to SRSF2. Deletion of this NRS allows SRSF2 to shuttle between the nucleus and cytoplasm, similar to the shuttling function of other SR proteins that aid in mRNA export [9]. 
It was recently discovered that SRSF2 is mutated in 10-15 \% of patients with Myelodysplastic syndrome (MDS) and $25-30 \%$ of patients with chronic myelomonocytic leukemia (CMML) [13-19]. Both of these diseases are aging-associated hematopoietic disorders that occur primarily in individuals over the age of 60 [20]. The only effective long term treatment for either disease is a bone marrow transplant, which is often not possible to perform due to both the age of the patients and a high relapse rate in patients with advanced disease [21-24]. While the cause of these disorders is still unknown, alternative splicing in genes related to hematopoiesis and cell cycle regulation, such as CDC25C and RUNX1, have been found in patients with MDS or AML $[25,26]$. For both of these diseases, patients with SRSF2 mutation have a miscoding of the proline at position 95 (P95) to a histidine, arginine, or leucine during the early stages of the disease. These mutations persist throughout the disease $[18,27]$. Recent research has also shown that P95 mutations of SRSF2 affect the ability of SRSF2 to bind its canonical splicing enhancer sequences in RNA [28, 29]. In addition, the P95H mutation of SRSF2 can increase death of hematopoietic cells and cause changes in hematopoiesis [28, 30]. Results from these studies support the notion that these mutations of SRSF2 are involved in MDS pathogenesis. However, the mechanism for how these mutations lead to disease development is still unknown.

We have constructed stable cell lines expressing from a Tet-inducible promoter HA-tagged wildtype SRSF2 (SRS$\mathrm{F} 2{ }^{\mathrm{WT}}$ ), HA-tagged SRSF2 with point mutations found in patients with MDS (SRSF2 ${ }^{\mathrm{P} 95 \mathrm{H}}, \mathrm{SRSF} 2^{\mathrm{P} 95 \mathrm{~L}}$, and SRSF2 ${ }^{\mathrm{P} 95 \mathrm{R}}$ ), and HA-tagged SRSF2 with in-frame deletions of each of the four major domains of the protein $\left(S R S F 2{ }^{\triangle R R M}=\right.$ deletion of the RNA recognition motif, SRSF $2^{\triangle H N G}=$ deletion of the hinge region, $S R S F 2^{\triangle R S}=$ deletion of the arginine/serine-rich domain, and SRSF2 ${ }^{\triangle \mathrm{NRS}}=$ deletion of the nuclear retention signal) in TF-1 erythroleukemia cells (Fig. 1a). Our data showed that while the SRSF2 ${ }^{\mathrm{P} 95 \mathrm{R} / \mathrm{L} / \mathrm{H}}$ mutations did not affect cellular localization of the protein, they did increase early apoptosis and affect the alternative splicing of CDC25C towards a shorter isoform (CDC25C-C5) that has previously been shown to be upregulated when DNA is damaged in breast cancer cells exposing to sub-lethal levels of doxorubicin and cisplatin [31]. Interestingly, we found SRSF2 mutant induced alternative splicing of CDC25C does not require activation of the DNA damage response pathway that is activated with cisplatin treatment.

\section{Methods}

\section{Plasmid construction}

The pRevTRE-SC35HA (SRSF2HA) tet-inducible plasmid was a gift from Xiang-Dong Fu's lab at UCSD
[2]. Mutations of P95 were produced using sitedirected mutagenesis with the QuikChange Kit (Agilent) with the following primers: SRSF2-P95X sense (5'-CTACGGCCGCCDCCCGGACTCAC-3') and SRSF2-P95X antisense (5'-GTGAGTCCGGGHGGCGGCCGTAG- $3^{\prime}$ ), where $\mathrm{D}$ is $\mathrm{A}, \mathrm{T}$, and $\mathrm{G}$ and $\mathrm{H}$ is $\mathrm{A}, \mathrm{T}$, and $\mathrm{C}$ [32]. SRSF2 deletion mutants were produced using the InFusion cloning system (Clontech) and primers that overlapped the deletion sites: $\triangle$ RRM F1 (ATGTGGAGGGTATGACCTCCATGGCGCGCTACGGC), $\triangle$ RRM R1 (GCCGTAGCGCGCCATGGAGGTCATACCCTCCACAT), $\triangle \mathrm{HNG}$ F1 (CGAGCTGCGGGIGCAAAGCCGCCGGGGACC), HNARIGGTCCCCG GCGGCTTTGCACCCGCAGCTCG), $\triangle$ RS F1 (CCCGGACTCACACCACCCTCCCCCAGTGTCCA), $\triangle \mathrm{RS}$ R1 (TGGACACTGGGGGAGGGTGGTGTGAGTCCGGG), $\triangle \mathrm{NRS}$ F1 (GGTCTCGGTCCAGGAGTCTCGAGTACCCATACGACG), $\triangle$ NRS R1 (CGTCGTATGGGTACTCGAGACTCCTGGACCGAGACC). SRSF2HA gene sequence was confirmed using Sanger sequencing. The lentiviral plasmid for expression of the reverse Tet transactivator protein (pHIV7-rtTA-V15), the plasmids for lentiviral packaging (pC-GP, pCMV-rev, pCMV-G), and the plasmids for retrovirus packaging (pCMV-GP and pCMV-G) were gifts from the lab of Jiing-Kwan Yee at City of Hope.

\section{Production and transduction of lentivirus and retrovirus}

For the rtTA lentivirus, 293T cells were transfected with pHIV7-rtTA, pC-GP-2, pCMV-rev2, and pCMV-G using calcium phosphate [32]. After $48 \mathrm{~h}$, cell supernatant was collected, filtered through a $0.45 \mu \mathrm{m}$ filter, and precipitated in a $10 \%$ PEG solution overnight at $4{ }^{\circ} \mathrm{C}$. Virus was then concentrated by centrifuging the PEG solution $30 \mathrm{~min}$ at $2000 \times g$. Supernatant was decanted and virus pellet was resuspended in the remaining solution. Virus was tittered on HT1080 cells by G418 resistance. TF-1 cells were transduced with rtTA lentivirus at an MOI of 0.003 for $48 \mathrm{~h}$ and then diluted to single cells and plated in 96-well plates for G418 selection. Single clones were collected and assayed for doxycyline induction potential. Clone \#6 was chosen as the TF-1 TetON parental cell line.

For the SRSF2HA retroviruses, 293T cells were transfected with the respective pRevTRE-SRSF2HA plasmid, pCMV-GP, and PCMV-G sing calcium phosphate transfection. After $48 \mathrm{~h}$, virus was collected as above. Virus was tittered on HT1080 cells by hygromycin B selection. TF-1 TetON cells were transduced with resulting retroviruses at an MOI of 0.1 for $48 \mathrm{~h}$. Each group was then selected for 2 weeks using hygromycin B to produce the TF-1 TetON SRSF2HA cell lines. 


\section{CDNA synthesis and RT-PCR}

$1 \times 10^{6}$ cells were pelleted and resuspended in $100 \mu \mathrm{l}$ Trizol. After 5 min incubation, $100 \mu \mathrm{l} 100 \% \mathrm{EtOH}$ was added and RNA was isolated using Direct-zol kit (Zymo Research). $1 \mu \mathrm{g}$ RNA was used for cDNA synthesis using either SuperScript III RT (Invitrogen) or PrimeScript RT (Clontech). Each RT-PCR reaction contained $10 \mu \mathrm{l} 2 \times$ Taq (BioPioneer), $0.5 \mu \mathrm{M}$ each primer, and $1 \mu \mathrm{l}$ cDNA. Primer list and reaction conditions can be found in Additional file 1: Table S1.

\section{Western Blot Analysis}

$1 \times 10^{6}$ cells were washed $1 \times$ with PBS and then resuspended in $50 \mu \mathrm{l} \mathrm{dH} 20.50 \mu \mathrm{l} 2 \times$ Laemmli buffer, prewarmed to $85{ }^{\circ} \mathrm{C}$, was added to each sample. Samples were incubated $10 \mathrm{~min}$ at $95{ }^{\circ} \mathrm{C}$. Samples were then aliquoted and flash frozen in liquid nitrogen to be stored at $-80{ }^{\circ} \mathrm{C}$. For SDS-PAGE, samples were diluted 3.5 -fold using $1 \times$ Laemmli buffer, and $7 \mu \mathrm{l}$ was loaded per lane. Following SDS-PAGE, proteins were transferred to PVDF membrane. The membranes were blocked for $1 \mathrm{~h}$ at RT with either $5 \%(\mathrm{w} / \mathrm{v})$ nonfat dry milk in TBST $(50 \mathrm{mM}$ Tris-Cl, pH 7.5. $150 \mathrm{mM} \mathrm{NaCl}, 0.1 \%$ Triton X-100) or $3 \%(w / v)$ BSA in TBST. Membranes were washed $3 \times$ with TBST. Primary antibodies [rabbit anti-HA tag (Abcam; ab9110; 1:10,000), mouse anti-GAPDH (Invitrogen; ZG003; 1:5000), mouse anti-SR proteins [1H4] (Santa Cruz Biotech; sc-13,509; 1:200), rabbit antiCDC25C [E303] (GeneTex; GTX61135; 1:500), rabbit anti-phospho CHK2 (Cell Signaling Technology; 2661; 1:2000), and mouse anti-phospho p53 [16G8] (Cell Signaling Technology; 9286; 1:500)] were diluted as stated in TBST and incubated overnight at $4{ }^{\circ} \mathrm{C}$. Membranes were washed $3 \times$ with TBST. Secondary antibodies [goat antirabbit IgG-IRDye 680LT (Li-Cor; 926-68021; 1:20,000), goat anti-mouse IgG-IRDye $800 \mathrm{CW}$ (Li-Cor; 926-32,210; 1:20,000), goat anti-rabbit-HRP (BioRad; 170-6515; 1:3000), and goat anti-mouse-HRP (BioRad; 170-6516; 1:3000)] were diluted as stated in TBST and incubated with the membranes for $4 \mathrm{~h}$ at RT. Membranes were washed $3 \times, 5$ min each wash, and subsequently scanned with an Odyssey machine (for Li-Cor secondaries) or exposed to X-ray film (for HRP secondaries).

\section{Immunoprecipitation}

$1 \times 10^{7}$ cells were pelleted for $5 \mathrm{~min}$ at $400 \times g$. Supernatant was removed and cells were resuspended in a buffer containing $50 \mathrm{mM}$ HEPES ( $\mathrm{pH} 7.8$ ), $3 \mathrm{mM} \mathrm{MgCl}_{2}$, $300 \mathrm{mM} \mathrm{NaCl}, 1 \mathrm{mM}$ DTT, $0.1 \mathrm{mM}$ PMSF, $1 \mathrm{X} \mathrm{Halt}^{\mathrm{TM}}$ Protease Inhibitor Cocktail (Thermoscientific), $5 \mathrm{mM} \mathrm{NaF}$, $2 \mathrm{mM} \mathrm{NaVO}, 0.5 \mathrm{U} / \mu \mathrm{l}$ DNase I, and $5 \mathrm{U} / \mu \mathrm{l}$ benzonase. Samples were incubated at $4{ }^{\circ} \mathrm{C}$ for $1 \mathrm{~h}$ with constant rotation, after which samples were centrifuged for $3 \mathrm{~min}$ at $4{ }^{\circ} \mathrm{C}, 10,000 \times g$. Supernatant was added to $50 \mu \mathrm{l}$ antiHA agarose beads (Sigma) and total volume was brought to $200 \mu \mathrm{l}$ with TBS. Samples were incubated overnight at $4{ }^{\circ} \mathrm{C}$ with constant end-over-end rotation. Agarose beads were pelleted for $10 \mathrm{~s}$ at $16,000 \mathrm{~g}$, and supernatant was removed as the unbound fraction. Pellet was washed $5 \times$ with TBST. Samples were eluted by incubating agarose beads with $50 \mu \mathrm{l} 1 \mathrm{mg} / \mathrm{ml}$ HA peptide (ThermoFisher Scientific) at $30^{\circ} \mathrm{C}$ for $15 \mathrm{~min}$. Eluate was assayed by Western blot.

\section{Immunofluoresecence}

Glass coverslips (Fisher Scientific; $22 \times 22-1.5$ ) were incubated with $0.01 \%$ poly-L-lysine (Sigma) for $10 \mathrm{~min}$. Poly-L-lysine solution was removed and coverslips were air-dried. $2 \times 10^{5}$ cells were incubated on coverslips $1 \mathrm{~h}$ at $37{ }^{\circ} \mathrm{C}$. Coverslips were washed $2 \times$ with PBS. Cells were fixed by incubating coverslips with $4 \%(\mathrm{w} / \mathrm{v})$ paraformaldehyde in PBS for 20 min at RT. Coverslips were then washed $2 \times$ with PBS and incubated 15 min at RT with $0.1 \%(\mathrm{v} / \mathrm{v})$ Triton X-100 in PBS. Cells were blocked by incubating coverslips overnight at $4{ }^{\circ} \mathrm{C}$ in $10 \%(\mathrm{v} / \mathrm{v})$ FBS in PBS. Coverslips were incubated with primary antibodies [rabbit anti-HA tag (Abcam; ab9110), mouse anti-SC35 (Abcam; ab11826), and mouse anti- $\gamma \mathrm{H} 2 \mathrm{AX}$ (ab11174)] each diluted 1:100 in the blocking solution for $1 \mathrm{~h}$ at RT. Coverslips were washed $5 \times$ with PBS and then incubated $1 \mathrm{~h}$ at RT with secondary antibodies [goat anti-rabbit IgG-AF647 (Jackson ImmunoResearch; 111-605-003) and goat anti-mouse IgG-AF488 (Jackson ImmunoResearch; 115-545-003)] diluted 1:100 in the blocking solution. Coverslips were then washed $5 \times$ with PBS and incubated $10 \mathrm{~min}$ at RT with $1 \times$ CellMask Orange (LifeTechnologies). Coverslips were then washed $3 \times$ with PBS and mounted on glass slides using VectaShield Hardset Mounting media with DAPI (Vector Laboratories). Slides were incubated overnight at $4{ }^{\circ} \mathrm{C}$ before imaged using a Zeiss LSM 700 confocal microscope. Analysis for HA-tagged protein localization was done using Image-Pro Plus (Media Cybernetics). The whole cell area was outlined in the Cell Mask Orange channel image and copied into the HA protein channel image. The nucleus was outlined in the DAPI channel image and also copied into the HA protein channel image. The integrated optical density (IOD) was analyzed independently for the whole cell and nucleus. The IOD for the cytoplasm alone was calculated by subtracting the IOD for the nucleus from the IOD of the whole cell.

\section{Apoptosis assay}

$1 \times 10^{5}$ cells were washed $1 \times$ with PBS. Cells were stained for 15 min using FITC-Annexin V and PI from FITC Annexin V Apoptosis Kit I (BD Pharmigen). 
Samples were then analyzed on a Cyan FACS machine. Cells were considered to be apoptotic based upon positive FITC detection. The stage of apoptosis was determined by the level of PI staining of the FITC-positive cells. Early apoptosis lacked any PI staining. Middle apoptosis had positive, albeit low levels of, PI staining. Late apoptosis was defined by high levels of PI staining.

\section{Cell proliferation assay}

$5 \times 10^{6}$ cells were stained on day 0 in $10 \mu \mathrm{M}$ CFSE (carboxyfluorescein succinimidyl ester, Thermo Fisher Scientific) for $15 \mathrm{~min}$ at $37^{\circ} \mathrm{C}$. Each day including day 0 , half of the cell culture was removed from the flask, washed $2 \times$ with PBS, fixed for $15 \mathrm{~min}$ in $4 \%$ (w/v) paraformaldehyde in water, washed $2 \times$ with PBS, and stored at $4{ }^{\circ} \mathrm{C}$ in the dark. After all time points for a single biological replicate were collected, samples were analyzed on a Cyan FACS machine. Data are plotted by using CFSE log mean.

\section{Cell cycle analysis}

$1 \times 10^{6}$ cells were washed $2 \times$ with PBS. Cells were resuspended in $500 \mu \mathrm{l}$ ice-cold $80 \% \mathrm{EtOH}$ and incubated overnight at $4{ }^{\circ} \mathrm{C}$. Cells were washed $2 \times$ with PBS, and resuspended in $0.25 \%$ Triton X-100, $20 \mu \mathrm{g} / \mathrm{ml}$ PI (propidium iodide), and $0.1 \mathrm{ng} / \mathrm{ml}$ RNase A. Cells were incubated overnight at $4{ }^{\circ} \mathrm{C}$. Samples were analyzed on a Cyan FACS machine. Data were analyzed using the cell cycle tool in Flowjo v6.

\section{Results}

\section{Characterization of SRSF2-HA-expressing cell lines}

We started our study by engineering a TF- 1 TetON cell line. The TF-1 cell line was chosen due to its classification as an erythroblast, allowing for inducible expression of an HA-tagged SRSF2 in a cell type similar to those commonly affected in MDS patients in order to examine phenotypic changes that may occur as a result of SRSF2 mutations. Furthermore, by PCR and Sanger sequencing, none of the common MDS-related mutations in U2AF1(S34), SF3B1(K700), or SRSF2(P95) were detected in the parental TF-1 cell line (data not shown).

We used site directed mutagenesis to produce eight different SRSF2 constructs: wildtype (SRSF2 ${ }^{\mathrm{WT}}$ ), each of the three MDS- and CMML-related point mutations (SRS$\mathrm{F} 2^{\mathrm{P} 95 \mathrm{H}}$, SRSF2 ${ }^{\mathrm{P} 95 \mathrm{~L}}$, and $\mathrm{SRSF2}{ }^{\mathrm{P} 95 \mathrm{R}}$ ), and four deletions for each of the primary domains of SRSF2 for comparison (SRSF2 ${ }^{\triangle R R M}, \mathrm{SRSF}^{\triangle \mathrm{HNG}}, \mathrm{SRSF}^{\triangle \mathrm{RS}}$, and SRSF2 ${ }^{\triangle \mathrm{NRS}}$ ) (Fig. 1a).

In order to assay for transgene expression, each of the SRSF2 cell lines (WT, P95H, P95L, P95R, $\triangle$ RRM, $\Delta$ HNG, $\triangle \mathrm{RS}$, and $\triangle \mathrm{NRS}$ ) and the parental TF-1 TetON cell line were cultured for $48 \mathrm{~h}$, both with and without induction using $2 \mu \mathrm{g} / \mathrm{ml}$ doxycycline. After $48 \mathrm{~h}$, protein and
RNA were isolated from each line. Western blotting using anti-HA antibodies detected the expression of HAtagged proteins with the expected size for each construct upon doxycycline induction (Fig. 1b). A small amount of the HA-tagged protein was expressed from the minimal CMV promoter without doxycycline induction (Additional file 2: Figure S1). The expression levels for $\mathrm{SRSF}^{\triangle \mathrm{RRM}}, \mathrm{SRSF} 2^{\triangle \mathrm{HNG}}$, and SRSF2 ${ }^{\triangle \mathrm{RS}}$ were noticeably lower than others (Fig. 1b, c). qRT-PCR of the ectopically expressed SRSF2-HA mRNAs showed no significant differences in the RNA level between the WT and mutants (Fig. 1d). Therefore, it appears that a deletion of the RRM, HNG, or RS domain negatively affects protein stability and/or efficient translation.

Since the hinge region of SRSF1 is required for kinase docking [12], we wanted to determine whether the disease-related P95 mutations of SRSF2, which occur in the hinge region, would affect the phosphorylation level of SRSF2. To this end, we immunoprecipitated the HA-tagged SRSF2 using an antibody against the HA tag. Western blots of the immunoprecipitated samples showed that SRSF2 ${ }^{\mathrm{P} 95 \mathrm{H}}, \mathrm{SRSF} 2^{\mathrm{P} 95 \mathrm{~L}}$, and $\mathrm{SRSF} 2^{\mathrm{P} 95 \mathrm{R}}$ were phosphorylated to the same level as SRSF2 ${ }^{\mathrm{WT}}$, as measured by anti-phospho-SR antibody (1H4 monoclonal antibody) while none of the deletion mutants showed detectable levels of phosphorylation (Fig. 1e, f).

As stated previously, unlike other SR proteins that are shuttled between the nucleus and the cytoplasm, SRSF2 is confined to the nucleus [9]. To examine whether any of the mutations would affect the cellular localization of SRSF2, we stained the tet-induced cells with anti-HA antibodies. Immunofluorescence results from the antiHA staining showed that SRSF2 ${ }^{\mathrm{WT}}$, SRSF2 ${ }^{\mathrm{P} 95 \mathrm{H}}$, SRS$\mathrm{F}^{\mathrm{P} 95 \mathrm{~L}}, \mathrm{SRSF}{ }^{\mathrm{P} 95 \mathrm{R}}, \mathrm{SRSF}^{\triangle \mathrm{RRM}}$, and SRSF2 ${ }^{\triangle \mathrm{HNG}}$ were all confined to the nucleus (Fig. 2a; Additional file 3: Figure S2a). SRSF2 ${ }^{\triangle \mathrm{NRS}}$ was located in both the nucleus and cytoplasm in agreement with previous studies showing that deletion of the NRS allows SRSF2 to shuttle between the nucleus and cytoplasm [9]. Unexpectedly, SRSF2 ${ }^{\Delta R S}$ was also present in both the nucleus and cytoplasm when it was expected to be located only in the cytoplasm due to loss of the primary nuclear localization signal $[9,33-35]$. It is possible that the remaining presence of the NRS allows for partial nuclear localization. We also stained each of the cell lines with an anti-SC35 antibody that specifically stains the nuclear phosphorylated SC35 speckles $[33,36]$. Previous research has shown that the phosphorylation state determines whether SRSF2/SC35 is localized within nuclear speckles [10]; therefore the pan-nuclear staining of HA-tagged SRSF2 indicated that a substantial portion of the HA-tagged protein is not in a phosphorylation state reserved for speckle localization. We also observed nuclear SC35-speckles with 


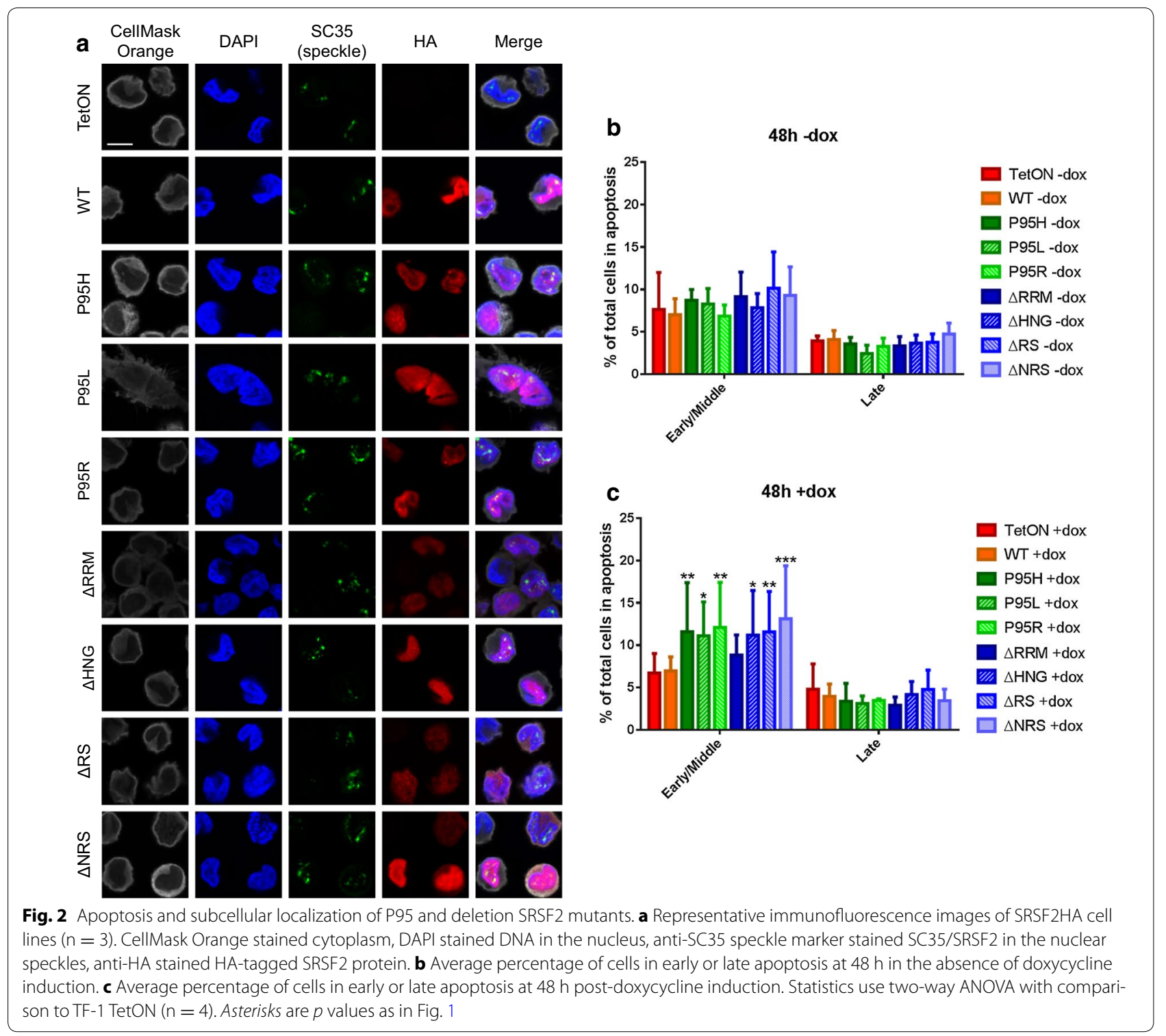

similar sizes and numbers among the cell lines, indicating the expression of the SRSF2-HA proteins did not significantly alter the formation or the dynamics of nuclear speckles (Fig. 2a).

Factors that can initiate an apoptotic signaling cascade, such as Fas, Fas- $\mathrm{L}$, tumor necrosis factor-a, and tumor necrosis factor-related apoptosis initiating ligand, are upregulated in bone marrow cells of MDS patients [37, 38], and it is thought that this increase in apoptosis in the bone marrow may contribute to the cytopenias that are a hallmark of MDS [39]. To assay our cell lines for changes in apoptosis, FITC-Annexin V and propidium iodide (PI) staining were used to determine apoptosis levels in each of the TF-1 cell lines (Additional file 3: Figure S2b).
Without doxycycline induction, there was no significant difference in apoptosis levels between any of the cell lines (Fig. 2b). However, with the doxycycline-induced expression of any of the three P95 mutant SRSF2 transgenes, cells showed a significant increase in early/middle apoptosis as compared to the SRSF ${ }^{\mathrm{WT}}$ and parental TetON cell lines (Fig. 2c). This result suggests that SRSF2 P95 mutations may be pro-apoptotic. We also noticed that $\mathrm{SRSF}^{\triangle \mathrm{HNG}}, \mathrm{SRSF} 2^{\triangle \mathrm{RS}}$, and SRSF2 ${ }^{\triangle \mathrm{NRS}}$ expressing cells also showed an increase in early/middle apoptosis as compared to the control cell lines, whereas SRSF2 $2^{\Delta R R M}$ showed no effect on apoptosis. We have also measured cell proliferation using CFSE staining. Upon staining, CFSE covalently binds intracellular molecules such as 
proteins, and as the cells divide the existing CFSE-bound proteins are redistributed to the daughter cells resulted in decreasing CFSE staining per cell. Thus, cell proliferation can be accurately measured by monitoring CFSE staining in cell culture [40]. By using CFSE staining, we did not observe significant change of cell proliferation with any of the SRSF2 mutants (Additional file 3: Figure S2c). Thus, increased apoptosis in SRSF2 ${ }^{\mathrm{P} 95 \mathrm{H} / \mathrm{L} / \mathrm{R}}$ is consistent with increased apoptosis of MDS cells.

\section{Alternative splicing changes}

SRSF2 is known to regulate alternative splicing of a number of pre-mRNAs including its own [41]. There are six splice variants of SRSF2 described in the database, and four of them were detected by RT-PCR in TF-1 cells using the primers depicted (Fig. 3a, b). Among these, splice isoforms $\mathrm{v} 3, \mathrm{v} 4$, and $\mathrm{v} 6$ are substrates of nonsensemediated decay (NMD) because they all have at least one intron that is more than 50 nucleotides downstream from the stop codon (Fig. 3a) [42]. The splice variant 5 (v5) has an intron 7 nucleotides downstream from the stop codon, which does not activate NMD, and is the predominant RNA species (Fig. 3b). As previously shown [41], SRSF2 ${ }^{\mathrm{WT}}$ overexpression promoted inclusion of alternative exons and resulted in an increase in isoform 4 expression as detected by RT-PCR (Fig. 3b, c). Similarly, expression of a $\mathrm{P} 95$ point mutant (SRSF2 ${ }^{\mathrm{P} 95 \mathrm{H}}$, SRSF2 ${ }^{\mathrm{P} 95 \mathrm{~L}}$, or SRSF2 ${ }^{\mathrm{P} 95 \mathrm{R}}$ ) also led to an increase of $\mathrm{v} 4$, indicating that these P95 mutations of SRSF2 do not affect its ability to auto-regulate its exon inclusion. On the contrary, expression of the RRM, RS, or HNG deletion mutants did not cause a significant increase of $\mathrm{v} 4$, while expression of $\mathrm{SRSF}^{\Delta \mathrm{NRS}}$ did (Fig. 3c). This supports previous findings that deletion of the NRS does not affect the alternative splicing function of SRSF2, whereas both the RRM and RS domains are required for this function [9, 33, 43-45].

We next investigated whether any of the SRSF2 mutants would alter splicing of other mRNAs that have been previously shown to be affected by SRSF2. To begin with, E2F1-mediated overexpression of SRSF2 has been shown to promote alternative splicing of a set of apoptosis-related genes to their pro-apoptotic form [46]. We assayed alternative splicing of BCL-X, caspase- 8 , and caspase- 9 by RT-PCR. At $48 \mathrm{~h}$ post-induction, we did not observe significant changes in alternative splicing in any of the SRSF2-expressing TF-1 cell lines (Additional file 4: Figure S3). Next, we assayed splice variants of BAP1 and TRA2A, which are found to change in mouse fibroblasts upon SRSF2 knock out [47]. We observed no significant splicing changes in these genes with doxycycline-induced overexpression of SRSF2 ${ }^{\mathrm{WT}}$ or any of the SRF2 mutants in TF-1 cells (Additional file 5: Figure S4).
We then analyzed the alternative splicing of CDC25C, a dual-specific phosphatase critical for the G2/M checkpoint pathway of the cell cycle. CDC25C has previously been found to be alternatively spliced in the bone marrow of patients with MDS [25]. In addition, CDC25C is part of the common deleted region in 5q- syndrome, the only subtype of MDS that has a defined cytogenetic cause and effective chemotherapy treatment [48-51]. Furthermore, haploinsufficiency of $\mathrm{CDC} 25 \mathrm{C}$ is required for effective lenalidomide treatment of patients with $5 \mathrm{q}$ - syndrome [52]. RT-PCR analysis of CDC25C revealed a distinctive change in the levels of the $\mathrm{C} 5$ isoform, which lacks exons 3,5 , and 6, relative to $C 1$ among the SRSF2 mutants. Specifically, expression of the MDS-associated point mutants (SRSF2 $^{\mathrm{P} 95 \mathrm{H}}$, SRSF2 ${ }^{\mathrm{P} 95 \mathrm{~L}}$, and SRSF2 ${ }^{\mathrm{P} 95 \mathrm{R}}$ ) each caused an increase in the CDC25C C5/C1 ratio (Fig. 4b, c). In contrast, expression of SRSF2 ${ }^{\mathrm{WT}}$ or the deletion mutants did not affect this ratio.

We then considered that this alternative splicing change may cause expression of a truncated CDC25C protein. Western blotting using an anti-CDC25C antibody, specific for the $\mathrm{C}$-terminus of the protein, detected the $\sim 60 \mathrm{kDa} \mathrm{CDC} 25 \mathrm{C} \mathrm{C} 1$ protein and an increased expression of a smaller protein isoform that corresponds to the expected $\sim 45 \mathrm{kDa}$ CDC25C C5 protein (Fig. $4 \mathrm{~d}$, e). This result indicated that expression of SRSF2 ${ }^{\mathrm{P} 95 \mathrm{H}}$, SRSF2 ${ }^{\mathrm{P} 95 \mathrm{R}}$, or $\mathrm{SRSF}^{\mathrm{P} 95 \mathrm{~L}}$ causes a splicing change of CDC25C mRNA, whereas expression of the SRSF2 deletion mutants or the wild-type protein does not produce the alternative splicing change.

\section{CDC25C alternative splicing and the DNA damage response}

The elevated ratio of $\mathrm{CDC} 25 \mathrm{C} \mathrm{C5/C1}$ detected in our TF-1 SRSF2-P95 mutants, has also been reported to be induced in breast cancer cells by treatment with sublethal doses of DNA-damaging agents, such as cisplatin (CIS) and doxorubicin [31]. To test whether DNA damaging agents would also alter alternative splicing of CDC25C in hematopoietic cells like TF-1, we treated TF-1 cells with various concentrations of CIS. As shown in Fig. 5a, $\mathrm{b}$ the ratio of $\mathrm{C} 5 / \mathrm{C} 1$ indeed increased when cells were treated with $40-50 \mu \mathrm{M}$ of CIS for $12 \mathrm{~h}$. CIS forms DNA crosslinks that can cause double-stranded breaks that activate the DNA damage response via the ATM pathway [53-55]. We also tested other drugs that induce the ATM DNA damage response pathway: camptothecin (CPT), a topoisomerase I poison that causes chromosomal breaks [56-58], and trichostatin A (TSA), a histone deacetylase inhibitor $[59,60]$. Similar to the effects observed with CIS treatment, CPT at $20-200 \mathrm{nM}$ for $6 \mathrm{~h}$ or TSA at $5-20 \mu \mathrm{M}$ for $12 \mathrm{~h}$ also caused an increase of the $\mathrm{C} 5$ splice variant of 

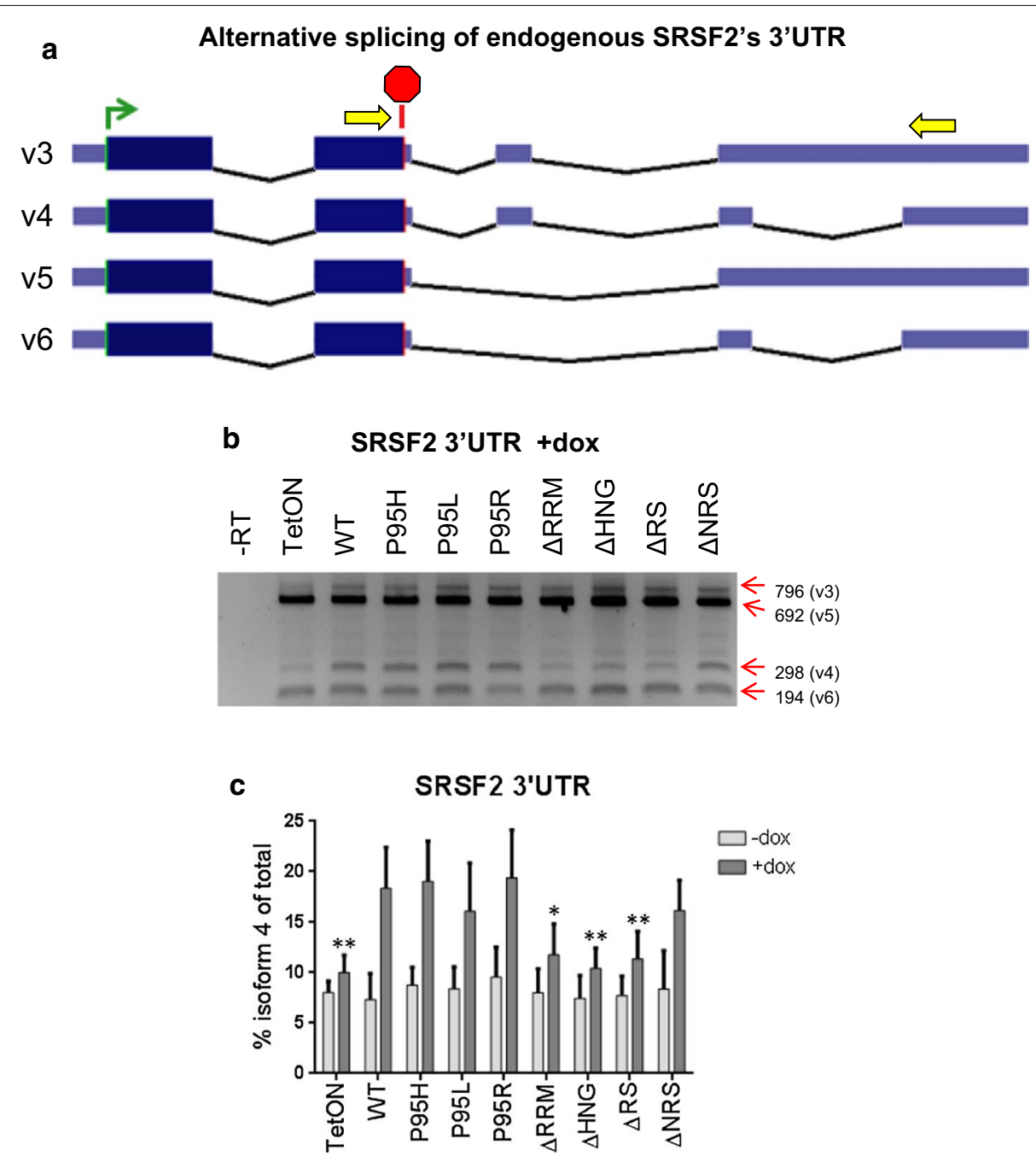

Fig. 3 Alternative splicing at the 3'UTR of endogenous SRSF2 transcripts. a Schematic of previously described SRSF2 isoforms (splice variants 3, 4, 5, and 6) that result from alternative splicing of the $3^{\prime} U T R$. Yellow arrows depict general location of primers used in RT-PCR. b Representative gel from RT-PCR of endogenous SRSF2's 3'UTR after $48 \mathrm{~h}$ treatment with $2 \mu \mathrm{g} / \mathrm{ml}$ doxycycline. The sizes in base pairs of the PCR products corresponding to the splice variants are labeled on the right. c Bar graphs depicting changes in \% isoform 4 (v4) of total RNA. Statistics are based on two-way ANOVA with comparison to SRSF2 ${ }^{W T}(n=4)$. Asterisks are pvalues as in Fig. 1; note that the data were compared to the WT and not to the tetON

CDC25C (Fig. 5c, d; Additional file 6: Figure S5a, b). We noticed that some RT-PCR signals were weak or barely detectable-this was evident in RNA samples from cells treated with high drug doses or extended time-likely resulted from low RNA yields under those conditions. Similar weak RT-PCR signals were also observed and used to quantify the ratio of $\mathrm{C} 5$ to $\mathrm{C} 1$ in heavily treated cells by Albert et al. [31]. We also analyzed the protein levels of the CDC25C isoforms by immune-blotting and found evidence consistent with a percent increase of the C5 protein isoform in cells treated with CIS, CPT, or TSA at a dosage that caused CDC25C alternative splicing (Additional file 6: Figure S5c, d).
Since agents that activate the ATM-mediated DNA damage response cause a similar splicing change (elevated $\mathrm{CDC} 25 \mathrm{C} \mathrm{C} / \mathrm{C} 1$ ) as the MDS-associated SRSF2 mutants, we wondered whether these point mutants may also activated the ATM-mediated DNA damage response. To test this, we examined whether the phosphorylation of ATM substrates (p53, CHK2, and H2A.X [61-68]) increases in the drug-treated cells and/or in the SRSF2 mutant expressing cells. Cell lysates were analyzed using Western blotting for phospho-p53 and phosphopCHK2. Treatment of the TF-1 TetON cell line with CIS, $\mathrm{CPT}$, or TSA led to an increase in both phospho-p53 and phospho-CHK2 compared to untreated TF-TetON cells, 

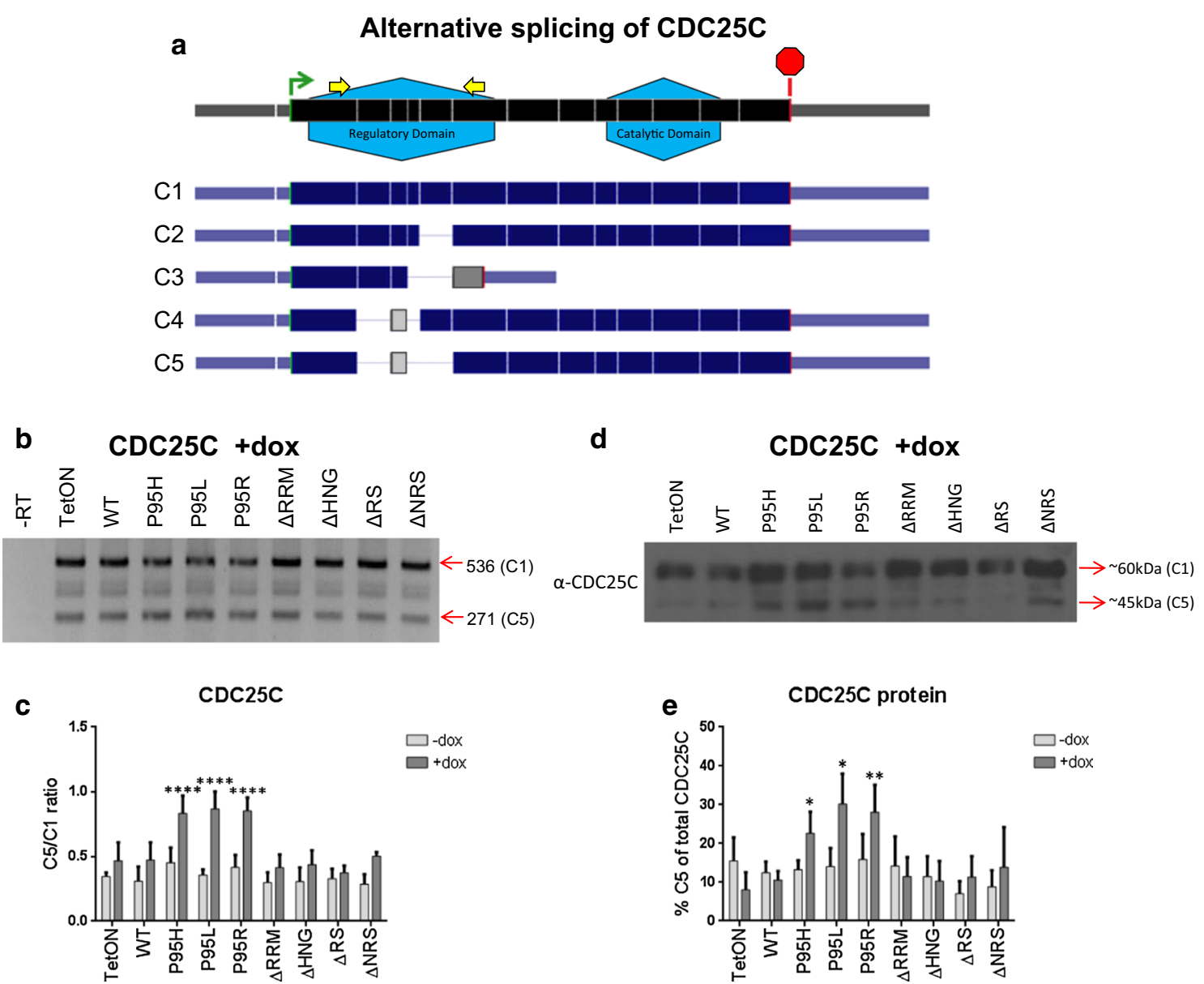

Fig. 4 Alternative splicing of CDC25C in SRSF2 mutant cell lines. a Schematic of previously described five CDC25C isoforms. Black is the CDC25C RNA with all 14 exons (the exon boundaries are marked). The general locations for the $\mathrm{N}$-terminal regulatory domain and the C-terminal catalytic domain, as well as the RT-PCR primers, are annotated. Dark blue is the known CDC25C alternative splicing transcripts. Gray depicts areas of frame shift that occurs with alternative splicing change in C3, C4, and C5. b Representative gel from RT-PCR of CDC25C after $48 \mathrm{~h}$ treatment with $2 \mu \mathrm{g} / \mathrm{ml}$ doxycycline. The sizes in base pairs of the PCR products corresponding to the splice variants are marked on the right. $\mathbf{c}$ Bar graphs depicting ratio of C5/C1 isoforms. Statistics are based on two-way ANOVA with comparison to SRSF2 ${ }^{\text {WT }}(n=5)$. d Western blot depicting CDC25C protein expression in the presence of doxycyline induction. e Graph depicting the Western results shown in D for CDC25C protein expression at $48 \mathrm{~h}$ post-induction. Statistics are based on two-way ANOVA with comparison to SRSF2WT $(n=5)$. Asterisks are $p$ values as in Fig. 1

as expected (Fig. 5e). However, ectopically expressing SRSF2 in TF-1 cells did not show a significant increase in phospho-p53 or phospho-CHK2 compared to doxycyline-treated TF-1 TetON, regardless of whether the SRSF2 was WT or a P95 mutant. We also tested levels of $\gamma \mathrm{H} 2 \mathrm{~A}$.X phosphorylation, a general marker for genome instability [69], in each of these cell lines. Again, CIS, $\mathrm{CPT}$, and TSA treatment each increased $\gamma \mathrm{H} 2 \mathrm{~A} . \mathrm{X}$ levels while none of the SRSF2 cell lines had an increase in $\gamma$ H2A.X (Fig. 5e; Additional file 7: Figure S6). In addition, by propidium iodide staining, none of the MDSrelated point mutants induced G2/M arrest (Additional file 8: Figure S7a). To test whether apoptosis played a role in $\mathrm{CDC} 25 \mathrm{C}$ alternative splicing, we added caspase inhibitor zVAD to block apoptosis in cells expressing SRSF2-P95 mutants. The ratio between splice variant C5 and C1 increased when SRSF2-P95 mutant expression was induced as expected; however, the addition of zVAD had no observable effect on CDC25C alternative splicing regardless whether SRSF2-P95 mutant expression was induced or not (Additional file 8: Figure S7B, C). This result indicated that apoptosis, although occurred in SRSF2-P95 mutant cells, was not responsible for the CDC25C alternative splicing. Taken together, it appears that the induction of $\mathrm{CDC} 25 \mathrm{C}$ alternative splicing by MDS-related SRSF2 point mutations does not require activation of classical ATM DNA damage response pathway. 

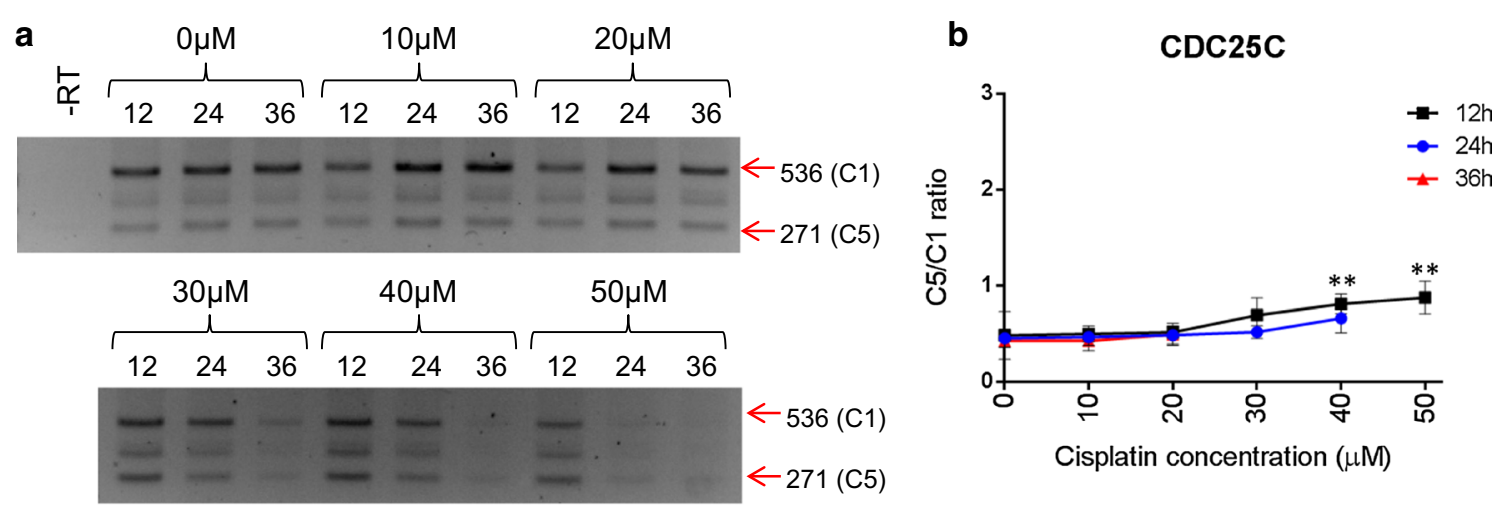

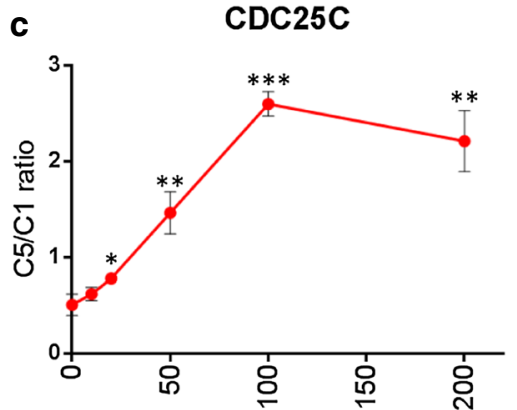

Camptothecin concentration (nM) d

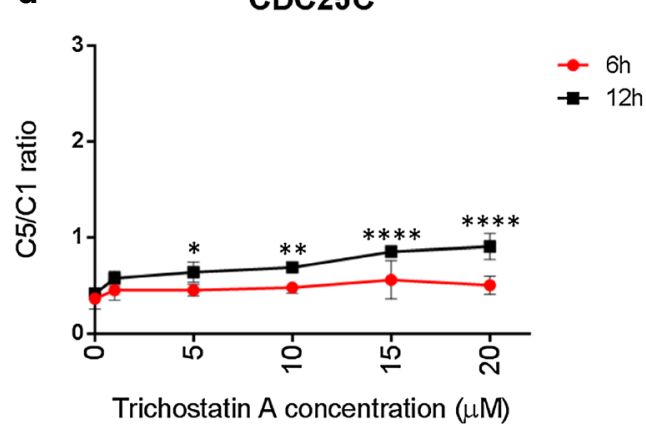

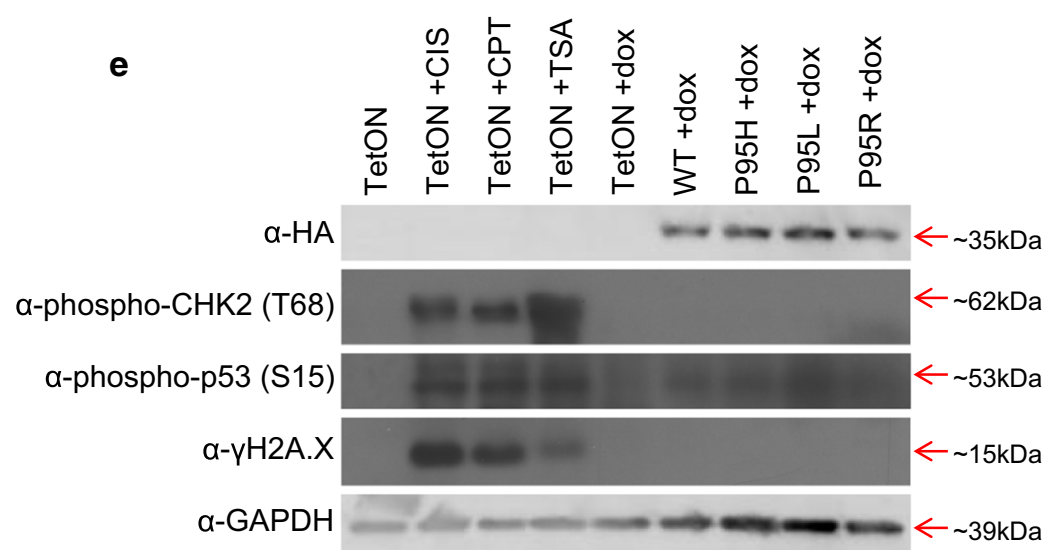

Fig. 5 Drug-induced CDC25C alternative splicing. a Representative RT-PCR gel of alternative splicing of CDC25C in response to cisplatin treatment. (b to d) Line graph depicting average C5/C1 ratios for CDC25C in TF-1 TetON cells treated with b cisplatin, c CPT, and d TSA treated TF-1 TetON cells. Statistics are determined by two-way ANOVA with comparison to $0 \mu \mathrm{M}(\mathrm{n}=4)$. e Western blot of HA-tagged protein, phosphorylated CHK2, phos-

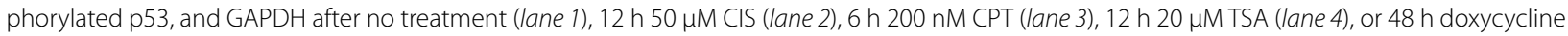
treatment (lanes 5-9). Asterisks are $p$ values as in Fig. 1

\section{Discussion}

Known functions of SRSF2 include regulation of constitutive and alternative splicing and maintenance of genome stability through the prevention of transcription-related R-loops [2, 3, 70]. Nearly half of all patients with MDS have mutation in a gene that regulates splicing. One of the most common mutations is the point mutation of proline 95 of SRSF2 to histidine, leucine, or arginine, which occurs in 15-20\% of all MDS patients. Recent research has shown that this mutation affects the RNA recognition specificity of SRSF2 and that the P95H mutation in a mouse model correlates with a phenotype similar to MDS [28-30]. However, the effect of SRSF2 mutation on distinct alternative splicing events remains 
poorly understood. In this study, we show that MDSrelated SRSF2 mutants act similar to wildtype SRSF2 in many ways, including phosphorylation and splicing of a select group of alternative splicing events. However, there is an alternative splicing change in CDC25C that is unique to $\mathrm{SRSF2}{ }^{\mathrm{P} 95}$ mutants. Chemotherapeutics that induce the classical ATM DNA damage response, including cisplatin, camptothecin, and trichostatin A, also induce an identical alternative splicing change in CDC25C.

Recent research has shown that various types of DNA damage can lead to post-translational modification of RNA-binding proteins, many of which have roles in the regulation of RNA splicing [71-75]. In fact, cisplatin treatment has been shown to cause increased translocation of SR protein kinases SRPK1 and SRPK2 to the nucleus leading to hyperphosphorylation of SRSF2 and reducing acetylation of SRSF2 [11]. In addition, activation of ATM- or ATR-mediated DNA damage response pathway has been shown to result in multiple changes in specific alternative splicing events, such as alternative splicing of apoptotic genes (BCL-X and caspase-8) [11, 76], DNA damage response genes (CHK1 and CHK2) [77, 78], and regulators of RNA splicing itself (TRA2, U2AF1, SRSF2 and SRSF1) [79-82]. However, the full changes in alternative splicing and their consequences for the DNA damage response still remain largely unknown.

Although it is known that $\mathrm{CDC} 25 \mathrm{C}$ alternative splicing occurs after treatment with genotoxic drugs, the affects of this alternative splicing on the DNA damage response (DDR) and cell fate is still undetermined. CDC25C protein undergoes various post-translation modifications during the DDR in order to either induce the G2/M checkpoint or apoptosis. One of the major post-translational modifications is phosphorylation at Ser216 by CHK2, which leads to interaction of CDC25C with the 14-3-3 complex and subsequent translocation of the CDC25C protein to the cytoplasm [83]. Without CDC25C present in the nucleus to activate CDK1 by dephosphorylation at Tyr15, the cell enters G2/M arrest. The $\mathrm{C} 5$ isoform of $\mathrm{CDC} 25 \mathrm{C}$ is upregulated during $\mathrm{S}$ phase, a cell cycle phase during which DNA repair frequently occurs due to DNA replication; however, the role of the $\mathrm{C} 5$ isoform in the $\mathrm{S}$ phase is not clear [84]. The alternative splicing of $\mathrm{CDC} 25 \mathrm{C}$, and its related protein CDC25A, is notable because it occurs primarily in the region of each transcript that encodes for the regulatory domain of the protein while leaving the catalytic domain intact (Fig. 4a) [84]. It is possible that alternative splicing of $\mathrm{CDC} 25 \mathrm{C}$, in conjunction with post-translational modification, plays an important regulatory role in cell fate after DNA damage. Interestingly, our results showed that the SRSF2 P95 point mutants cause the same alternative
CDC25C splicing change without activating conventional DDR.

CDC25C is part of the commonly deleted region in 5q-syndrome, and effective treatment of 5q- syndrome with lenalidomide requires haploinsufficiency of CDC25C [48-52]. Furthermore, alternative splicing of $\mathrm{CDC} 25 \mathrm{C}$ has already been observed in bone marrow samples from patients with MDS [25]. In addition, mutations in DNA damage response genes, such as p53 (TP53) and ATM, are found in MDS patients without 5-q deletion [85], and MDS-related U2AF1 mutations lead to alternative splicing in the DNA damage response genes ATR and FANCA [86]. Therefore, it appears that CDC25C may be recurrently misregulated in MDS through gene deletion, aberrant DNA damage response, or aberrant splicing factors like SRSF2-P95 mutants and U2AF1 mutants.

\section{Conclusion}

In conclusion, our data support a model where MDSrelated SRSF2 mutants lead to alternative splicing of $\mathrm{CDC} 25 \mathrm{C}$ that increases the percentage of the $\mathrm{C} 5$ isoform among all the $\mathrm{CDC} 25 \mathrm{C}$ variants. This alternative splicing event can also be induced by cisplatin, camptothecin, or trichostatin A treatment. However, the SRSF2 point mutants do not lead to phosphorylation of CHK2 or p53, which is readily detected in the drug-treated cells. Therefore, SRSF2P95H/L/R-mediated CDC25C alternative splicing changes do not require activation of the classical ATM DDR. The mechanism of CDC25C alternative splicing and its downstream effects may be pertinent to the role of SRSF2's point mutation in the development of myelodysplastic syndrome.

\section{Additional files}

Additional file 1. Supplementary information: supplemental figure legends, supplemental references, and Table S1.

Additional file 2: Figure S1. HA-tagged SRSF2 protein expression in uninduced TF-1 cell lines.

Additional file 3: Figure S2. Apoptosis, subcellular localization, and cell proliferation of SRSF2 mutants.

Additional file 4: Figure S3. Alternative splicing of apoptosis genes.

Additional file 5: Figure S4. Alternative splicing of genes from a previous study using SRSF2 depletion.

Additional file 6: Figure S5. Alternative splicing of CDC25C in TF-1 cells treated with CIS, CPT, or TSA.

Additional file 7: Figure S6. DNA damage in SRSF2 mutant cell lines.

Additional file 8: Figure S7. Cell cycle analysis of SRSF2 mutant cells and the effect of an apoptosis inhibitor on CDC25C alternative splicing.

Abbreviations

SRSF2: serine-arginine rich splicing factor 2; MDS: myelodysplastic syndrome; CDC25C: cell division cycle 25C; ATM: ataxia telangiectasia mutated; RRM: RNA 
recognition motif; RS: serine-arginine rich domain; HNG: hinge region; NRS: nuclear retention signal; CMML: chronic myelomonocytic leukemia.

\section{Authors' contributions}

$L S$ and RJL conceived the project; LS, JMS, and RJL designed experiments; LS performed experiments; LS, JMS, and RJL analyzed the data; and LS, JMS, and RJL wrote the paper. All authors read and approved the final manuscript.

\section{Author details}

${ }^{1}$ Department of Molecular and Cellular Biology, Irell \& Manella Graduate School of Biological Sciences, Beckman Research Institute of the City of Hope, Duarte, CA 91010, USA. ${ }^{2}$ Department of Cancer Genetics and Epigenetics, Irell \& Manella Graduate School of Biological Sciences, Beckman Research Institute of the City of Hope, Duarte, CA 91010, USA.

\section{Acknowledgements}

We thank Xiang-Dong Fu of UCSD for plasmid pRevTRE-SC35HA (SRSF2HA) and Jiing-Kuan Yee of City of Hope for plasmids pHIV7-rtTA, pC-GP-2, pCMVrev2, pCMV-G, and pCMV-GP.

\section{Competing interests}

The authors declared that they have no competing interests.

\section{Funding}

LS was supported in part by the H.N. \& Frances Berger Foundation Fellowship and the Norman and Melinda Payson Fellowship. This work was supported by grants from the Beckman Research Institute to RJL, National Institutes of Health Grant R01-CA1 20954 to JMS, and by NIH Grant P30-CA033572 for shared research core facilities at City of Hope.

Received: 12 March 2016 Accepted: 16 August 2016

Published online: 23 August 2016

\section{References}

1. Li X, Manley JL. Inactivation of the SR protein splicing factor ASF/SF2 results in genomic instability. Cell. 2005;122(3):365-78.

2. Xiao R, Sun Y, Ding JH, Lin S, Rose DW, Rosenfeld MG, Fu XD, Li X. Splicing regulator SC35 is essential for genomic stability and cel proliferation during mammalian organogenesis. Mol Cell Biol. 2007;27(15):5393-402.

3. Lin S, Coutinho-Mansfield G, Wang D, Pandit S, Fu XD. The splicing factor SC35 has an active role in transcriptional elongation. Nat Struct Mol Biol. 2008;15(8):819-26.

4. Sollier J, Stork CT, Garcia-Rubio ML, Paulsen RD, Aguilera A, Cimprich KA. Transcription-coupled nucleotide excision repair factors promote R-loopinduced genome instability. Mol Cell. 2014;56(6):777-85.

5. Ji X, Zhou Y, Pandit S, Huang J, Li H, Lin CY, Xiao R, Burge CB, Fu XD. SR proteins collaborate with 7SK and promoter-associated nascent RNA to release paused polymerase. Cell. 2013;153(4):855-68.

6. Fu XD, Maniatis T. The 35-kDa mammalian splicing factor SC35 mediates specific interactions between $\mathrm{U} 1$ and $\mathrm{U} 2$ small nuclear ribonucleoprotein particles at the $3^{\prime}$ splice site. Proc Natl Acad Sci USA. 1992:89(5):1725-9.

7. Caceres JF, Screaton GR, Krainer AR. A specific subset of SR proteins shuttles continuously between the nucleus and the cytoplasm. Genes Dev. 1998;12(1):55-66.

8. Wang C, Chua K, Seghezzi W, Lees E, Gozani O, Reed R. Phosphorylation of spliceosomal protein SAP 155 coupled with splicing catalysis. Genes Dev. 1998;12(10):1409-14.

9. Cazalla D, Zhu J, Manche L, Huber E, Krainer AR, Caceres JF. Nuclear export and retention signals in the RS domain of SR proteins. Mol Cell Biol. 2002;22(19):6871-82

10. Hall LL, Smith KP, Byron M, Lawrence JB. Molecular anatomy of a speckle. Anat Rec A Discov Mol Cell Evol Biol. 2006;288(7):664-75.

11. Edmond V, Moysan E, Khochbin S, Matthias P, Brambilla C, Brambilla E, Gazzeri S, Eymin B. Acetylation and phosphorylation of SRSF2 control cell fate decision in response to cisplatin. EMBO J. 2011;30(3):510-23.
12. Ngo JCK, Chakrabarti S, Ding J-H, Velazquez-Dones A, Nolen B, Aubol BE, Adams JA, Fu X-D, Ghosh G. Interplay between SRPK and Clk/Sty kinases in phosphorylation of the splicing factor ASF/SF2 is regulated by a docking motif in ASF/SF2. Mol Cell. 2005;20(1):77-89.

13. Patnaik MM, Lasho TL, Finke CM, Hanson CA, Hodnefield JM, Knudson RA, Ketterling RP, Pardanani A, Tefferi A. Spliceosome mutations involving SRSF2, SF3B1, and U2AF35 in chronic myelomonocytic leukemia: prevalence, clinical correlates, and prognostic relevance. Am J Hematol. 2013:88(3):201-6.

14. Itzykson R, Solary E. An evolutionary perspective on chronic myelomonocytic leukemia. Leukemia. 2013:27(7):1441-50.

15. Yoshida K, Sanada M, Shiraishi Y, Nowak D, Nagata Y, Yamamoto R, Sato Y, Sato-Otsubo A, Kon A, Nagasaki M, et al. Frequent pathway mutations of splicing machinery in myelodysplasia. Nature. 2011;478(7367):64-9.

16. Damm F, Kosmider O, Gelsi-Boyer V, Renneville A, Carbuccia N, HidalgoCurtis C, Della Valle V, Couronne L, Scourzic L, Chesnais V, et al. Mutations affecting mRNA splicing define distinct clinical phenotypes and correlate with patient outcome in myelodysplastic syndromes. Blood. 2012;119(14):3211-8.

17. Thol F, Kade S, Schlarmann C, Loffeld P, Morgan M, Krauter J, Wlodarski MW, Kolking B, Wichmann M, Gorlich K, et al. Frequency and prognostic impact of mutations in SRSF2, U2AF1, and ZRSR2 in patients with myelodysplastic syndromes. Blood. 2012;119(15):3578-84.

18. Wu SJ, Kuo YY, Hou HA, Li LY, Tseng MH, Huang CF, Lee FY, Liu MC, Liu CW, Lin CT, et al. The clinical implication of SRSF2 mutation in patients with myelodysplastic syndrome and its stability during disease evolution. Blood. 2012;120(15):3106-11.

19. Federmann B, Abele M, Rosero Cuesta DS, Vogel W, Boiocchi L, Kanz L, Quintanilla-Martinez L, Orazi A, Bonzheim I, Fend F. The detection of SRSF2 mutations in routinely processed bone marrow biopsies is useful in the diagnosis of chronic myelomonocytic leukemia. Hum Pathol. 2014;45(12):2471-9.

20. Ma X, Does M, Raza A, Mayne ST. Myelodysplastic syndromes: incidence and survival in the United States. Cancer. 2007:109(8):1536-42.

21. Koreth J, Pidala J, Perez WS, Deeg HJ, Garcia-Manero G, Malcovati L, Cazzola M, Park S, Itzykson R, Ades L, et al. Role of reduced-intensity conditioning allogeneic hematopoietic stem-cell transplantation in older patients with de novo myelodysplastic syndromes: an international collaborative decision analysis. J Clin Oncol. 2013;31(21):2662-70.

22. Negrin RS, Haeuber DH, Nagler A, Kobayashi Y, Sklar J, Donlon T, Vincent M, Greenberg PL. Maintenance treatment of patients with myelodysplastic syndromes using recombinant human granulocyte colony-stimulating factor. Blood. 1990;76(1):36-43.

23. Legare RD, Gilliland DG. Myelodysplastic syndrome. Curr Opin Hematol. 1995:2(4):283-92.

24. Appelbaum FR, Anderson J. Allogeneic bone marrow transplantation for myelodysplastic syndrome: outcomes analysis according to IPSS score. Leukemia. 1998;12(Suppl 1):S25-9.

25. Caudill JS, Porcher JC, Steensma DP. Aberrant pre-mRNA splicing of a highly conserved cell cycle regulator, CDC25C, in myelodysplastic syndromes. Leuk Lymphoma. 2008;49(5):989-93.

26. Makishima H, Visconte V, Sakaguchi H, Jankowska AM, Abu Kar S, Jerez A, Przychodzen B, Bupathi M, Guinta K, Afable MG, et al. Mutations in the spliceosome machinery, a novel and ubiquitous pathway in leukemogenesis. Blood. 2012;119(14):3203-10.

27. Matsuda K, Ishida F, Ito T, Nakazawa H, Miura S, Taira C, Sueki A, Kobayashi Y, Honda T. Spliceosome-related gene mutations in myelodysplastic syndrome can be used as stable markers for monitoring minimal residual disease during follow-up. Leuk Res. 2012;36(11):1393-7.

28. Kim E, llagan JO, Liang Y, Daubner GM, Lee SC, Ramakrishnan A, Li Y, Chung YR, Micol JB, Murphy ME, et al. SRSF2 mutations contribute to myelodysplasia by mutant-specific effects on exon recognition. Cancer Cell. 2015;27(5):617-30.

29. Zhang J, Lieu YK, Ali AM, Penson A, Reggio KS, Rabadan R, Raza A, Mukherjee S, Manley JL. Disease-associated mutation in SRSF2 misregulates splicing by altering RNA-binding affinities. Proc Natl Acad Sci USA. 2015:112(34):E4726-34.

30. Komeno Y, Huang YJ, Qiu J, Lin L, Xu Y, Zhou Y, Chen L, Monterroza DD, Li $\mathrm{H}$, DeKelver RC, et al. SRSF2 is essential for hematopoiesis, and its myelodysplastic syndrome-related mutations dysregulate alternative pre-mRNA splicing. Mol Cell Biol. 2015;35(17):3071-82. 
31. Albert H, Battaglia E, Monteiro C, Bagrel D. Genotoxic stress modulates CDC25C phosphatase alternative splicing in human breast cancer cell lines. Mol Oncol. 2012;6(5):542-52.

32. Li MJ, Rossi JJ. Lentivirus transduction of hematopoietic cells. Cold Spring Harb Protoc. 2007;2007(5):pdb.prot4755.

33. Caceres JF, Misteli T, Screaton GR, Spector DL, Krainer AR. Role of the modular domains of SR proteins in subnuclear localization and alternative splicing specificity. J Cell Biol. 1997;138(2):225-38.

34. Li H, Bingham PM. Arginine/serine-rich domains of the su(wa) and tra RNA processing regulators target proteins to a subnuclear compartment implicated in splicing. Cell. 1991;67(2):335-42.

35. Hedley ML, Amrein H, Maniatis T. An amino acid sequence motif sufficient for subnuclear localization of an arginine/serine-rich splicing factor. Proc Natl Acad Sci USA. 1995;92(25):11524-8.

36. Misteli T, Caceres JF, Spector DL. The dynamics of a pre-mRNA splicing factor in living cells. Nature. 1997;387(6632):523-7.

37. Zang DY, Goodwin RG, Loken MR, Bryant E, Deeg HJ. Expression of tumor necrosis factor-related apoptosis-inducing ligand, Apo2L, and its receptors in myelodysplastic syndrome: effects on in vitro hemopoiesis. Blood. 2001;98(10):3058-65.

38. Gersuk GM, Beckham C, Loken MR, Kiener P, Anderson JE, Farrand A, Troutt AB, Ledbetter JA, Deeg HJ. A role for tumour necrosis factor-alpha, Fas and Fas-Ligand in marrow failure associated with myelodysplastic syndrome. Br J Haematol. 1998;103(1):176-88.

39. Parker JE, Fishlock KL, Mijovic A, Czepulkowski B, Pagliuca A, Mufti GJ. 'Low-risk' myelodysplastic syndrome is associated with excessive apoptosis and an increased ratio of pro-versus anti-apoptotic bcl-2-related proteins. Br J Haematol. 1998;103(4):1075-82.

40. Lyons AB, Blake SJ, Doherty KV. Flow cytometric analysis of cell division by dilution of CFSE and related dyes. Curr Protoc Cytom. 2013;9:9-11.

41. Sureau A, Gattoni R, Dooghe Y, Stevenin J, Soret J. SC35 autoregulates its expression by promoting splicing events that destabilize its mRNAs. EMBO J. 2001;20(7):1785-96.

42. Nagy E, Maquat LE. A rule for termination-codon position within introncontaining genes: when nonsense affects RNA abundance. Trends Biochem Sci. 1998;23(6):198-9.

43. Mayeda A, Screaton GR, Chandler SD, Fu XD, Krainer AR. Substrate specificities of SR proteins in constitutive splicing are determined by their RNA recognition motifs and composite pre-mRNA exonic elements. Mol Cell Biol. 1999;19(3):1853-63.

44. Kongruttanachok N, Phuangphairoj C, Thongnak A, Ponyeam W, Rattanatanyong P, Pornthanakasem W, Mutirangura A. Replication independent DNA double-strand break retention may prevent genomic instability. Mol Cancer. 2010:9:70

45. Kumar A, Rai PS, Upadhya R, Vishwanatha Prasada KS, Rao BS, Satyamoorthy K. Gamma-radiation induces cellular sensitivity and aberrant methylation in human tumor cell lines. Int J Radiat Biol. 2011;87(11):1086-96.

46. Merdzhanova G, Edmond V, De Seranno S, Van den Broeck A, Corcos L, Brambilla C, Brambilla E, Gazzeri S, Eymin B. E2F1 controls alternative splicing pattern of genes involved in apoptosis through upregulation of the splicing factor SC35. Cell Death Differ. 2008:15(12):1815-23.

47. Pandit S, Zhou Y, Shiue L, Coutinho-Mansfield G, Li H, Qiu J, Huang J, Yeo GW, Ares M Jr, Fu XD. Genome-wide analysis reveals SR protein cooperation and competition in regulated splicing. Mol Cell. 2013;50(2):223-35.

48. Bunn HF. 5q- and disordered haematopoiesis. Clin Haematol. 1986;15(4):1023-35.

49. Pedersen B, Kerndrup G. Specific minor chromosome deletions consistently occurring in myelodysplastic syndromes. Cancer Genet Cytogenet. 1986;23(1):61-75.

50. Ebert BL. Deletion $5 q$ in myelodysplastic syndrome: a paradigm for the study of hemizygous deletions in cancer. Leukemia. 2009;23(7):1252-6.

51. Jadersten $\mathrm{M}$, Karsan A. Clonal evolution in myelodysplastic syndromes with isolated del $(5 q)$ : the importance of genetic monitoring. Haematologica. 2011;96(2):177-80.

52. Wei S, Chen X, Rocha K, Epling-Burnette PK, Djeu JY, Liu Q, Byrd J, Sokol L, Lawrence N, Pireddu R, et al. A critical role for phosphatase haplodeficiency in the selective suppression of deletion $5 q$ MDS by lenalidomide. Proc Natl Acad Sci USA. 2009;106(31):12974-9.

53. Jordan P, Carmo-Fonseca M. Molecular mechanisms involved in cisplatin cytotoxicity. Cell Mol Life Sci. 2000;57(8-9):1229-35.
54. Colton SL, Xu XS, Wang YA, Wang G. The involvement of ataxiatelangiectasia mutated protein activation in nucleotide excision repair-facilitated cell survival with cisplatin treatment. J Biol Chem. 2006;281(37):27117-25.

55. Mu XF, Jin XL, Farnham MM, Li Y, O'Neill C. DNA damage-sensing kinases mediate the mouse 2-cell embryo's response to genotoxic stress. Biol Reprod. 2011;85(3):524-35.

56. Ryan AJ, Squires S, Strutt HL, Johnson RT. Camptothecin cytotoxicity in mammalian cells is associated with the induction of persistent double strand breaks in replicating DNA. Nucleic Acids Res. 1991;19(12):3295-300.

57. Sordet O, Redon CE, Guirouilh-Barbat J, Smith S, Solier S, Douarre C, Conti C, Nakamura AJ, Das BB, Nicolas E, et al. Ataxia telangiectasia mutated activation by transcription- and topoisomerase I-induced DNA doublestrand breaks. EMBO Rep. 2009;10(8):887-93.

58. Marinello J, Chillemi G, Bueno S, Manzo SG, Capranico G. Antisense transcripts enhanced by camptothecin at divergent $\mathrm{CpG}$-island promoters associated with bursts of topoisomerase I-DNA cleavage complex and R-loop formation. Nucleic Acids Res. 2013;41 (22):10110-23.

59. Lee JS. Activation of ATM-dependent DNA damage signal pathway by a histone deacetylase inhibitor, trichostatin A. Cancer Res Treat. 2007:39(3):125-30.

60. Ju R, Muller MT. Histone deacetylase inhibitors activate p21(WAF1) expression via ATM. Cancer Res. 2003;63(11):2891-7.

61. Banin S, Moyal L, Shieh S, Taya Y, Anderson CW, Chessa L, Smorodinsky NI, Prives C, Reiss Y, Shiloh Y, et al. Enhanced phosphorylation of p53 by ATM in response to DNA damage. Science. 1998:281(5383):1674-7.

62. Canman CE, Lim DS, Cimprich KA, Taya Y, Tamai K, Sakaguchi K, Appella E, Kastan MB, Siliciano JD. Activation of the ATM kinase by ionizing radiation and phosphorylation of p53. Science. 1998;281(5383):1677-9.

63. Chaturvedi P, Eng WK, Zhu Y, Mattern MR, Mishra R, Hurle MR, Zhang X, Annan RS, Lu Q, Faucette LF, et al. Mammalian Chk2 is a downstream effector of the ATM-dependent DNA damage checkpoint pathway. Oncogene. 1999;18(28):4047-54.

64. Matsuoka S, Huang M, Elledge SJ. Linkage of ATM to cell cycle regulation by the Chk2 protein kinase. Science. 1998;282(5395):1893-7.

65. Matsuoka S, Rotman G, Ogawa A, Shiloh Y, Tamai K, Elledge SJ. Ataxia telangiectasia-mutated phosphorylates Chk2 in vivo and in vitro. Proc Natl Acad Sci USA. 2000;97(19):10389-94.

66. Burma S, Chen BP, Murphy M, Kurimasa A, Chen DJ. ATM phosphorylates histone $\mathrm{H} 2 \mathrm{AX}$ in response to DNA double-strand breaks. J Biol Chem. 2001:276(45):42462-7.

67. Fernandez-Capetillo O, Chen HT, Celeste A, Ward I, Romanienko PJ, Morales JC, Naka K, Xia Z, Camerini-Otero RD, Motoyama N, et al. DNA damage-induced G2-M checkpoint activation by histone H2AX and 53BP1. Nat Cell Biol. 2002:4(12):993-7.

68. Stiff T, O'Driscoll M, Rief N, Iwabuchi K, Lobrich M, Jeggo PA. ATM and DNA-PK function redundantly to phosphorylate $\mathrm{H} 2 \mathrm{AX}$ after exposure to ionizing radiation. Cancer Res. 2004;64(7):2390-6.

69. Dickey JS, Redon CE, Nakamura AJ, Baird BJ, Sedelnikova OA, Bonner WM. H2AX: functional roles and potential applications. Chromosoma. 2009;118(6):683-92.

70. Paulsen RD, Soni DV, Wollman R, Hahn AT, Yee MC, Guan A, Hesley JA, Miller SC, Cromwell EF, Solow-Cordero DE, et al. A genome-wide siRNA screen reveals diverse cellular processes and pathways that mediate genome stability. Mol Cell. 2009;35(2):228-39.

71. Beli P, Lukashchuk N, Wagner SA, Weinert BT, Olsen JV, Baskcomb L, Mann $\mathrm{M}$, Jackson SP, Choudhary C. Proteomic investigations reveal a role for RNA processing factor THRAP3 in the DNA damage response. Mol Cell. 2012:46(2):212-25.

72. Bennetzen MV, Larsen DH, Bunkenborg J, Bartek J, Lukas J, Andersen JS. Site-specific phosphorylation dynamics of the nuclear proteome during the DNA damage response. Mol Cell Proteomics. 2010;9(6):1314-23.

73. Blasius M, Forment JV, Thakkar N, Wagner SA, Choudhary C, Jackson SP. A phospho-proteomic screen identifies substrates of the checkpoint kinase Chk1. Genome Biol. 2011;12(8):R78.

74. Adamson B, Smogorzewska A, Sigoillot FD, King RW, Elledge SJ. A genome-wide homologous recombination screen identifies the RNAbinding protein RBMX as a component of the DNA-damage response. Nat Cell Biol. 2012;14(3):318-28. 
75. Mastrocola AS, Kim SH, Trinh AT, Rodenkirch LA, Tibbetts RS. The RNA-binding protein fused in sarcoma (FUS) functions downstream of poly(ADP-ribose) polymerase (PARP) in response to DNA damage. J Biol Chem. 2013;288(34):24731-41.

76. Shkreta L, Michelle L, Toutant J, Tremblay ML, Chabot B. The DNA damage response pathway regulates the alternative splicing of the apoptotic mediator BCl-x. J Biol Chem. 2011;286(1):331-40.

77. Best A, James K, Dalgliesh C, Hong E, Kheirolahi-Kouhestani M, Curk T, Xu Y, Danilenko M, Hussain R, Keavney B, et al. Human Tra2 proteins jointly control a CHEK1 splicing switch among alternative and constitutive target exons. Nat Commun. 2014;5:4760.

78. Paronetto MP, Minana B, Valcarcel J. The Ewing sarcoma protein regulates DNA damage-induced alternative splicing. Mol Cell. 2011;43(3):353-68.

79. Katzenberger RJ, Marengo MS, Wassarman DA. Control of alternative splicing by signal-dependent degradation of splicing-regulatory proteins. J Biol Chem. 2009;284(16):10737-46.

80. Filippov V, Filippova M, Duerksen-Hughes PJ. The early response to DNA damage can lead to activation of alternative splicing activity resulting in CD44 splice pattern changes. Cancer Res. 2007;67(16):7621-30.

81. Solier S, Barb J, Zeeberg BR, Varma S, Ryan MC, Kohn KW, Weinstein JN, Munson PJ, Pommier Y. Genome-wide analysis of novel splice variants induced by topoisomerase I poisoning shows preferential occurrence in genes encoding splicing factors. Cancer Res. 2010;70(20):8055-65.
82. Colla S, Ong DS, Ogoti Y, Marchesini M, Mistry NA, Clise-Dwyer K, Ang SA, Storti P, Viale A, Giuliani N, et al. Telomere dysfunction drives aberrant hematopoietic differentiation and myelodysplastic syndrome. Cancer Cell. 2015;27(5):644-57.

83. Bulavin DV, Higashimoto Y, Popoff IJ, Gaarde WA, Basrur V, Potapova O, Appella E, Fornace AJ Jr. Initiation of a G2/M checkpoint after ultraviolet radiation requires p38 kinase. Nature. 2001;411(6833):102-7.

84. Wegener S, Hampe W, Herrmann D, Schaller HC. Alternative splicing in the regulatory region of the human phosphatases CDC25A and CDC25C. Eur J Cell Biol. 2000;79(11):810-5.

85. Haferlach T, Nagata Y, Grossmann V, Okuno Y, Bacher U, Nagae G, Schnittger S, Sanada M, Kon A, Alpermann T, et al. Landscape of genetic lesions in 944 patients with myelodysplastic syndromes. Leukemia. 2014;28(2):241-7.

86. Ilagan JO, Ramakrishnan A, Hayes B, Murphy ME, Zebari AS, Bradley P, Bradley RK. U2AF1 mutations alter splice site recognition in hematological malignancies. Genome Res. 2015;25(1):14-26.

\section{Submit your next manuscript to BioMed Central and we will help you at every step:}

- We accept pre-submission inquiries

- Our selector tool helps you to find the most relevant journal

- We provide round the clock customer support

- Convenient online submission

- Thorough peer review

- Inclusion in PubMed and all major indexing services

- Maximum visibility for your research

Submit your manuscript at www.biomedcentral com/submit 